\title{
Primary hyperaldosteronism due to an adrenal adenoma in a 14-year-old boy
}

\author{
J Rodriguez-Arnao, L Perry, JE Dacie, R Reznek, RJM Ross
}

\begin{abstract}
Summary
Conn's syndrome due to an adrenal adenoma is very rare in children. This paper reports a 14-year-old boy with primary hyperaldosteronism due to an adrenal adenoma. His biochemistry data were compatible with either bilateral adrenal hyperplasia or an adrenal adenoma. A dexamethasone test did not suppress aldosterone levels. Venous catheter sampling and ${ }^{75}$ Se-selenomethylcholesterol scanning suggested that the hyperaldosteronism originated at the right adrenal. Computed tomography showed an $8-\mathrm{mm}$ low-density nodule in the right adrenal gland and magnetic resonance imaging confirmed the nodule which had high signal intensity on T2-weighted images consistent with a functioning adenoma. Surgery confirmed the right adrenal adenoma, and the patient was cured by right adrenalectomy. This case illustrates the difficulty of defining the aetiology of primary hyperaldosteronism and we review the biochemical and scanning techniques available to aid in diagnosis. Hypertension is unusual in children and endocrine causes are very rare, but Conn's syndrome should always be considered in the differential diagnosis.
\end{abstract}

Keywords: hyperaldosteronism, adrenal adenoma

\section{Introduction}

The incidence of hypertension in the paediatric population is very low, ${ }^{1}$ and endocrine causes of hypertension are infrequent (see box). ${ }^{2-5}$ The majority of children with hypersecretion of aldosterone have bilateral hyperplasia. ${ }^{6} \mathrm{We}$ describe the case of a boy with Conn's syndrome (hyperaldosteronism due to an adrenal adenoma ${ }^{7}$ ) and discuss the different techniques available to diagnose this infrequent cause of hypertension.

\begin{tabular}{|c|c|}
\hline $\begin{array}{l}\text { St Bartholomew's } \\
\text { Hospital, London } \\
\text { EC1A 7BE, UK } \\
\text { Department of } \\
\text { Endocrinology } \\
\text { J Rodriguez-Arnao } \\
\text { L Perry } \\
\text { RJM Ross } \\
\text { Department of } \\
\text { Radiology } \\
\text { JE Dacie }\end{array}$ & $\begin{array}{l}\text { population is very low, }{ }^{1} \text { and endocrine causes of } \\
\text { hypertension are infrequent (see box) } .^{2-5} \text { The } \\
\text { majority of children with hypersecretion of } \\
\text { aldosterone have bilateral hyperplasia. }{ }^{6} \text { We } \\
\text { describe the case of a boy with Conn's synd- } \\
\text { rome }(\text { hyperaldosteronism due to an adrena } \\
\text { adenoma }^{7} \text { ) and discuss the different techniques } \\
\text { available to diagnose this infrequent cause of } \\
\text { hypertension. }\end{array}$ \\
\hline Correspondence to & Primary hyperaldosteronism \\
\hline $\begin{array}{l}\text { Department of } \\
\text { Endocrinology, St } \\
\text { Bartholomew's Hospital, } \\
\text { London EC1A 7BE, UK }\end{array}$ & $\begin{array}{l}\text { - } 0.05-2 \% \text { adult hypertensives } \\
\text { suspect if there is hypokalaemia } \\
\text { - } 3 \text { rd-6th decades } \\
\text { - more common in women } \\
\text { extremely rare in children }\end{array}$ \\
\hline
\end{tabular}

\section{Case report}

A 14-year-old Afro-Caribbean male was referred to the medical out-patients clinic with a two-month history of increasing frontal headaches. His general practitioner reported the blood pressure to be $200 / 130 \mathrm{mmHg}$. He had a past medical history of asthma and a family history of 'essential' hypertension. On examination he was a tall, slim boy, at stage 4 puberty, pulse 84 beats min, blood pressure lying $200 / 130 \mathrm{mmHg}$ and standing $180 /$ $120 \mathrm{mmHg}$. He had no radio-femoral delay, bruit or dysmorphic features. Fundoscopy revealed a retinal infarct, and he had a loud second heart sound. The rest of the examination was normal. Our investigations showed normal renal function, with normal urea and creatinine, serum sodium levels of $143 \mathrm{mmol} / \mathrm{l}$ (normal range: 135-146) and a serum potassium level of $3.0 \mathrm{mmol} / 1$ (normal range: $3.5-5.0) ; 24 \mathrm{~h}$ urinary free catecholamines were normal. Electrocardiogram and echocardiogram showed left ventricular hypertrophy. Ultrasound of his kidneys was normal. The aldosterone level at midday after four hours standing was elevated on two occasions despite a fall in cortisol on one occasion; a result previously reported to suggest bilateral hyperplasia. Neither aldosterone nor renin activity changed during a captopril test (25 $\mathrm{mg})$, suggesting primary hyperaldosteronism. A dexamethasone suppression test $(0.5 \mathrm{mg}$ six hourly for five days) failed to suppress aldosterone levels excluding the possibility of glucocorticoid-suppressible hyperaldosteronism. A ${ }^{75} \mathrm{Se}$-selenomethylcholesterol $\operatorname{scan}^{8}$ showed twice the uptake in the right adrenal gland compared with the left, suggesting a possible right adrenal adenoma. Venous catheter sampling confirmed the increased aldosterone production from the right adrenal (see table).

A computed tomographic (CT) scan was performed (General Electric 9000) using $5 \mathrm{~mm}$ collimation and scanning contiguously both before and after intravenous injection of contrast medium. This technique showed an 8-mm low density nodule in the right adrenal gland. Because of the absence of retroperitoneal fat and the age of the patient, magnetic resonance imaging (MRI) was also performed using a 1.5 Tesla General Electric scanner. T1- (TR 340, TE 20) and T2-weighted (TR 2000, TE 100) sequences were obtained, and these confirmed the presence of the small nodule in the right 
Table Biochemical results

\begin{tabular}{|c|c|c|c|}
\hline & $\begin{array}{l}\text { Aldosterone } \\
\text { (pmol/l) }\end{array}$ & $\begin{array}{l}\text { Renin } \\
(\text { pmol } / l / h)\end{array}$ & $\begin{array}{l}\text { Cortisol } \\
(\mathrm{nmol} / \mathrm{l})\end{array}$ \\
\hline \multicolumn{4}{|l|}{ Day -1} \\
\hline lying $(09.00 \mathrm{~h})$ & 1140 & $<60$ & 380 \\
\hline standing $(13.00 \mathrm{~h})$ & 1381 & $<60$ & 221 \\
\hline \multicolumn{4}{|l|}{ Day 2} \\
\hline lying $(09.00 \mathrm{~h})$ & 1482 & $<60$ & 439 \\
\hline standing $(13.00 \mathrm{~h})$ & 1717 & $<60$ & 496 \\
\hline \multicolumn{4}{|l|}{ Captopril test $(25 \mathrm{mg})$} \\
\hline time 0 & 1377 & $<60$ & - \\
\hline time $120 \mathrm{~min}$ & 1278 & $<60$ & - \\
\hline \multicolumn{4}{|c|}{ Dexamethasone suppression test $(0.5 \mathrm{mg} \text { qds on days } 0-5)^{\star}$} \\
\hline day -1 & 1482 & - & - \\
\hline day 3 & 1997 & - & - \\
\hline day 4 & 1881 & - & - \\
\hline day 5 & 1158 & - & - \\
\hline day 6 & 1556 & - & - \\
\hline \multicolumn{4}{|l|}{ Adrenal catheter } \\
\hline right adrenal & 33000 & - & 6137 \\
\hline peripheral & 2102 & - & 609 \\
\hline left adrenal & 4430 & - & 8393 \\
\hline peripheral & 2001 & - & 567 \\
\hline
\end{tabular}

Normal ranges: aldosterone: lying $135-440 \mathrm{pmol} / \mathrm{l}$, standing $330-830 \mathrm{pmol} / \mathrm{l}$; renin: lying $230-1000 \mathrm{pmol} / \mathrm{l} / \mathrm{h}$, standing $460-1550 \mathrm{pmol} / \mathrm{l} / \mathrm{h}$; cortisol: $300-$ $700 \mathrm{nmol} / 1$ (adult, $09.00 \mathrm{~h}$ ). *measured lying.

adrenal. This was of low signal intensity relative to the liver on $\mathrm{T} 1$-weighted images and of high signal intensity relative to the liver on T2-weighted images. These appearances are consistent with a functioning adenoma.

A right adrenalectomy was performed. An adrenal gland weighing $3 \mathrm{~g}$ and measuring $5 \times 2.5 \times 1.5 \mathrm{~cm}$ was removed. Histology showed a well circumscribed nodule arising from the cortex of the adrenal gland, divided into lobules by thin, discontinuous fibrous septae. No mitosis were seen and there was no evidence of atypia or malignancy, the features were compatible with an adrenal cortical adenoma. Post-operatively the patient made a quick recovery, maintained normal blood pressure and was on no therapy at discharge. One month after his adrenalectomy his headaches had resolved, his potassium was $4.3 \mathrm{mmol} / 1$ and his blood pressure was $125 / 80 \mathrm{mmHg}$.

\section{Discussion}

Primary hyperaldosteronism should be suspected in all hypertensive patients with spontaneous hypokalaemia. ${ }^{3}$ Conn's syndrome (hyperaldosteronism due to an adrenal adenoma) in childhood is extremely rare, however, defining the cause is vital as this will determine whether the child has lifelong medical treatment or surgery. Our case illustrates the difficulty in differentiating hyperaldosteronism due to bilateral adrenal hyperplasia from an aldosterone-producing adrenal adenoma.

Different methods for differentiating the adenoma, the hyperplasia and idiopathic forms have been described (see box). ${ }^{5}$ Plasma aldosterone levels usually decrease in patients with aldosterone-producing adrenal adenomas during upright posture in the morning, but increase in patients with adrenal hyperplasia. $^{9-11}$ These observations reflect that aldosterone-producing adrenal adenomas ap-

\section{Adrenal adenoma or hyperplasia?}

- lying and standing plasma aldosterone levels

- single dose captopril test

- dexamethasone suppression test

- CT scan of adrenals

- adrenal venous sampling

pear to be sensitive to the control by corticotrophin (ACTH), whereas adrenal hyperplasia is dominated by the renin - angiotensin axis. In our patient with an adrenal adenoma, however, plasma aldosterone levels did not decline during four hours standing, despite a decline in the plasma cortisol level, results which would be compatible with hyperaldosteronism due to bilateral adrenal hyperplasia.

The single-dose captopril test has been proposed for the diagnosis of primary hyperaldosteronism. ${ }^{12}$ Captopril is an inhibitor of the angiotensin-converting enzyme and blocks the conversion of angiotensin I to angiotensin II. In normal subjects captopril should inhibit the production of angiotensin II and hence aldosterone, and, by feed-back control, increase plasma renin activity. In patients where production of aldosterone is autonomous it has been postulated that captopril should have little effect on either plasma aldosterone or plasma renin. However, the results of the captopril test may be inconclusive. ${ }^{13}$ Our patient, after a captopril test dose of $25 \mathrm{mg}$, showed a flat response in his aldosterone and renin levels, suggesting the existence of an independent adrenal aldosterone source.

Patients with primary hyperaldosteronism and a family history of hypertension should also undergo evaluation for the possibility of glucocorticoid-suppressible hyperaldosteronism. Dexamethasone treatment will return the serum potassium, blood pressure and aldosterone levels to normal in patients with glucocorticoid-suppressible hyperaldosteronism. In our patient, failure to suppress aldosterone production by dexamethasone excluded glucocorticoid-suppressible hyperaldosteronism.

Another differential diagnosis to be excluded in a patient presenting with hypokalaemia and hypertension is a deficiency of $11 \beta$-hydroxysteroid dehydrogenase (an enzyme that is responsible for the interconversion of cortisol and cortisone), and that is characterised by low levels of aldosterone and renin. In these patients cortisol acts as a potent mineralocorticoid. ${ }^{14}$ In our patient, the high aldosterone levels excluded this syndrome, which can be both hereditary and acquired.

Adrenal CT scanning has been recommended as the initial imaging procedure to distinguish between aldosterone-producing adrenal adenomas and adrenal hyperplasia in patients with primary hyperaldosteronism. ${ }^{4}$ The diagnostic sensitivity of CT scanning has been reported to be as high as $82-88 \%{ }^{15,16}$ However, although a diagnostic accuracy of $90 \%$ in patients with aldosterone-producing 
adrenal adenomas has been described, ${ }^{4}$ and adenomas as small as $7 \mathrm{~mm}$ can be identified, ${ }^{16}$ it is still important to correlate CT scan findings with the endocrine studies. ${ }^{17}$ In our patient both CT and MR scanning detected the very small adenoma.

Selective adrenal venous sampling was one of the first tests used to distinguish aldosteroneproducing adrenal adenomas from adrenal hyperplasia. ${ }^{18-20}$ Although it continues to be the most accurate test when both adrenal veins are sampled, it is invasive and a difficult technique. In our patient it confirmed the origin of the increased aldosterone level and it was performed with no significant side-effects.

1 Sinaiko AR, Gomez-Marin O, Prineas RJ. Prevalence of 'significant' hypertension in junior high school-aged children: the children and adolescents pressure program. $f$ Pediatr 1989; 114: 664-9.

2 Hiramatsu K, Yamada T, Yukimura Y, et al. A screening test to identify aldosterone-producing adenoma by measuring plasma renin activity. Arch Intern Med 1981; 141: 1589-93 3 Melby JC. Clinical review 1: Endocrine hypertension. $f$ Clin Endocrinol Metab 1989; 69: 697-703.

4 Young WF Jr, Hogan MJ, Klee GG, Grant CS, VaunHeerden JA. Primary aldosteronism: diagnosis and treatment. Mayo Clin Proc 1990; 65: 96-110

5 Ferris JB, Brown JJ, Fraser R, Lever AF, Robertson JIS. 5 Ferris JB, Brown JJ, Fraser R, Lever AF, Robertson JIS. 10: 419-52.

6 Oberfield SE, Levine LA, Firpo A, et al. Primary hyperaldosteronism in childhood due to unilateral hyperplasia. Case report. Hypertension 1984; 6: 75-84.

7 Conn JW. Primary hyperaldosteronism: a new clinical syndrome. F Lab Clin Med 1955; 45: 6-17.

8 Shapiro B, Britton KE, Hawkins LA, Edwards CRW Clinical experience with ${ }^{75}$ Se-selenomethylcholesterol adrenal imaging. Clin Endocrinol 1981; 15: 19-27.

9 Ganguly A, Melada GA, Luetscher JA, Dowdy AJ. Control of plasma aldosterone in primary hyperaldosteronism: distinction between adenoma and hyperplasia. $\exists$ Clin Endocrinol Metab 1973; 37: 765-75.

10 Schambelan M, Brust NL, Chang BCF, Slater KL, Biglieri EG. Circadian rhythm and effect of posture on plasma aG. Circadian rhythm and effect of posture on plasma Endocrinol Metab 1976; 43: 115-31.

11 Wisgerhof M, Brown RD, Hogan MJ, Carpenter PC, Edis AJ. The plasma aldosterone response to angiotensin II infusion in aldosterone-producing adenoma and idiopathic hyperaldosteronism. F Clin Endocrinol Metab 1981; 52 195-8.
In summary, we report a 14-year-old male, in whom the diagnosis of primary aldosteronism was established by the presence of hypertension refractory to conventional medical treatment, spontaneous hypokalaemia, metabolic alkalosis and relative hypernatraemia. CT scan, MRI, ${ }^{75} \mathrm{Se}-$ selenomethylcholesterol scanning and a selective adrenal sampling suggested an adrenal adenoma, which was confirmed at surgery.

JRA is supported by a grant (93/0747) from Fondo de Investigaciones Sanitarias (Spain).

12 Lyons DF, Kem DC, Brown RD, Hanson CS, Carollo ML Single dose captopril as a diagnostic test for prima aldosteronism. $\mathcal{F}$ Clin Endocrinol Metab 1983; 57: 892-6.

13 Hambling C, Jung RT, Gunn A, Browning MCK, Bartlett WA. Re-evaluation of the captopril test for the diagnosis of primary hyperaldosteronism. Clin Endocrinol 1992; 36: 499-503.

14 Stewart PM, Corrie JET, Shackleton CHL, Edwards CRW. Syndrome of apparent mineralocorticoid excess: a defect in the cortisol-cortisone shuttle. $\mathcal{F}$ Clin Invest 1988; 82: 340-9.

15 Ikeda DM, Francis IR, Glazer GM, Amendola MA, Gross $\mathrm{MD}$, Aisen AM. The detection of adrenal tumours and hyperplasia in patients with primary aldosteronism: comhyperplasia in patients with primary aldosteronism: comparison of scintigraphy, CT

16 Dunnick NR, Leight GS, Roubidoux MA, Leder RA, Paulson E, Kurylo L. CT in the diagnosis of primary aldosteronism: sensitivity in 29 patients. Am $\mathcal{F}$ Roentgeno 1993; 160: 321-4

17 Radin DR, Manoogian C, Nadler JL. Diagnosis of primary hyperaldosteronism: importance of correlating CT findings with endocrinologic studies. Am $\mathcal{F}$ Roentgenol 1992; 158: 553-7.

18 Melby JC, Sparks RF, Dale SL, Egdahl RH, Kahn PC Diagnosis and localization of aldosterone-producing adenomas by adrenal vein catheterization. $N$ Engl $f \mathrm{Med}$ 1967; 277: 1050-6.

19 Kahn PC, Kelleher MD, Egdahl RH, Melby JC. Adrenal arteriography and venography in primary aldosteronism. Radiology 1971; 101: 71-8.

20 Ganguly A, Bergstein J, Grim CE, Yum MO, Weinberger MH. Childhood primary aldosteronism due to an adrenal MH. Childhood primary aldosteronism due to an adrenal catheterization. Pediatrics 1980; 65: 605-9. 